\title{
Simulation of an Advanced GeOthermal Energy Conversion Plant in Perú
}

\author{
Sofía Chauca Paredes* \\ https://orcid.org/0000-0003-1220-6842 \\ Graciela Rojas García* \\ https://orcid.org/0000-0001-6833-4267 \\ GeORge PoWer PoRTo* \\ https://orcid.org/0000-0001-6444-6085 \\ Universidad de Lima, Perú
}

Recibido: 9 de marzo del 2021 / Aprobado: 21 de junio del 2021

doi: https://doi.org/10.26439/ing.ind2021.n41.5546

ABSTRACT: This investigation aims to simulate an efficient plant that generates energy through a solar-geothermal hybrid energy conversion system with supercritical steam, Therminol VP1, geothermal fluid and R134a refrigerant. The goal is to exemplify a hybrid solution that optimizes and takes advantage of the existing properties of the solar and geothermal power cycles. The geothermal part of the process, the primary cycle, is augmented by the solar thermal cycle to obtain a high-efficiency result.

In addition, it allows the reader to understand the ideal process of this type of plant and a thermodynamic analysis represented by creating a detailed model block flow diagram, which is then turned into a dynamic one used to examine the selected parameters such as temperature, flow rate, and pressure variations. The dynamic model approximated the thermal values of the heat exchangers and the working fluids in the exchangers, solar collectors, piping and in the storage tanks.

KEYWORDS: geothermal energy / simulation / flash plant / renewable energy / conversion plant

\footnotetext{
*Correo electrónicos: 20152836@aloe.ulima.edu.pe; 20142223@aloe.ulima.edu.pe; Gpower@ulima.edu.pe
} 


\section{SIMULACIÓN DE UNA PLANTA AVANZADA DE CONVERSIÓN DE ENERGÍA GEOTÉRMICA EN PERÚ}

RESUMEN: Esta investigación tiene como objetivo simular una planta eficiente que genere energía a través de un sistema híbrido geotérmico solar con vapor supercrítico, Terminol VP1, agua, fluido geotérmico y refrigerante R134a. Tiene como objetivo que, a través de la solución híbrida, se optimice y aproveche las propiedades existentes de los ciclos de energía solar y geotérmica. De esta manera, la parte geotérmica del proceso se convierte en el ciclo principal, complementado por el ciclo solar térmico, con la finalidad de obtener como resultado una eficiencia elevada.

Asimismo, permite al lector entender el proceso ideal de este tipo de planta, así como un análisis termodinámico. Este se representa a través de un modelo detallado en un diagrama de flujo de bloques, que luego se convierte en uno dinámico, utilizado para examinar los parámetros seleccionados como las variaciones de temperatura, caudal y presión. El modelo dinámico aproximó los valores térmicos de los intercambiadores de calor y los fluidos de trabajo en los intercambiadores, los colectores solares, las tuberías y en los depósitos de almacenamiento.

PALABRAS CLAVE: energía geotérmica / simulación / planta flash / energía renovable / planta de conversión 


\section{INTRODUCTION}

According to the International Energy Agency, 72,6\% of the countries members of the Organization for Economic Co-operation and Development (OECD) generated electricity from non-renewable energy sources in 2018 (The International Energy Agency [IEA], 2018). Among the main sources employed are coal, oil, and natural gas, responsible for most greenhouse gas emissions. In Peru, the main sources of electricity production are hydropower and natural gas, representing $94,3 \%$ of the total energy produced as of October 2020 (Comité de Operaciones del Sistema Interconectado Nacional, 2020).

Multiple studies, like Assessing the impact of renewable energy deployment on local sustainability: Towards a theoretical framework (Burguillo \& Del Río, 2008), Renewable energy and sustainable development: a crucial review (Dincer, 2000), and Renewable energy sources and social movements in Latin America (Mendoza \& Pérez, 2010) demonstrate that the adoption of renewable energy sources would have a positive impact on the environment. According to Akella et al. (2009), these impacts would include a reduction in the emission of polluting gases, a slowdown in climate change, a reduction in acid rain, protection of the ozone layer, and an improvement in the population's health.

Due to the reasons presented above, the country has a regulatory and institutional framework that promotes renewable energy resources, composed of the following legal framework: Legislative Decree N. ${ }^{\circ} 1002$ - Promotion of investment for the generation of electricity with the use of renewable energy; Supreme Decree N. ${ }^{\circ}$ 012-2011-EM Regulations for the generation of electricity with renewable energy; Supreme Decree N. ${ }^{\circ} 020-2013-E M$ - Regulations for the promotion of electricity investment in areas not connected to the grid (off-grid); and Ministerial Resolution N. ${ }^{\circ}$ 203-2013-MEM/DM - Plan for universal access to energy.

In 2008, the development of non-conventional renewable energy generation projects began through public auctions organized by the Ministry of Energy and Mines (MINEM) at least every two years; in which the Supervisory Agency for Investment in Energy and Mining (OSINERGMIN) is responsible for setting the maximum prices and supervising that the contracts are fulfilled. These auctions offer contracts that guarantee the energy purchase for periods between 10 and 30 years, long-term stable tariffs, subsidies if the marginal cost is lower than the tariff, and monetary funds for research and development (Vasquez et al., 2017).

Among the different types of renewable energy resources, solar, wind, biomass, mini-hydro, marine and geothermal energy are considered. The latter is the energy obtained by taking advantage of the earth's interior heat through groundwater, which can reach boiling temperatures that will drive steam turbines (Osinergmin, 2013). This type of energy is contained in the rock and fluids beneath the earth's crust that generates 
surface phenomena as lava flows, geysers, fumaroles, hot springs, and mud pots (Lund, 2018). This energy is also present even below the coldest parts of the earth's crust. In most places, the earth's heat is trapped at depths of more than 20 miles. This type of energy can be used in three ways: direct-use applications, geothermal heat pumps (GHPs), and electric power generation.

The direct use is the most common. It is for warming a single building and whole districts with numerous buildings with a central supply source. Also, it can be used for swimming pools, spas, greenhouses, among others. The geothermal heat pumps can heat buildings during the cold months and cool them in the warmer ones by circulating underground water. It is a system made up of a heat exchanger and a pump. It is very efficient, using less electricity than conventional heating and cooling systems, and producing less greenhouse gas emissions. Finally, it also can be used to generate electricity, a form of renewable energy. It collects rising steam from the ground and then feeds it into a turbine that drives an electrical generator (Lund, 2018.). Some advantages of using this type of energy are:

- It does not depend on weather conditions and has very high-capacity factors.

- It can be extracted without burning a fossil fuel such as coal, gas, or oil.

- Geothermal fields produce much less carbon dioxide than a clean natural gasfueled power plant does.

- It saves as much as 80 percent of investment/operating costs as it is relatively inexpensive compared to fossil fuels (National Geographic, n.d.).

Geothermal energy also has some disadvantages, including environmental problems. It releases hydrogen sulfide, disposes some geothermal fluids with low levels of toxic materials, and, finally, the geothermal source in some locations may cool down, or the well production may decrease (Lund, 2018). On the other hand, geothermal energy generates almost no $\mathrm{CO}_{2}$ emissions since it does not produce any combustion compared to a coal plant; furthermore, it requires little water and significantly less space than a coal or wind farm (Vásquez et al., 2017).

The implementation costs vary according to the technology used: dry steam plants, flash plants, or binary cycle plants. For 50 MW capacity, a binary plant costs about 4141 USD/kW, while a dual flash plant amounts to 6163 USD/kW (U.S. Energy Information Administration, 2010).

One type of geothermal energy system is the solar-geothermal hybrid plant. This system increasies the steam flow during the present geothermal cycle, adding a solar field of parabolic trough concentrators. This procedure can help increase the capacity factor by generating additional steam during the peak demand hours (Lentz \& Almanza, 
2006). There are several types of designs for this cycle, like geothermal-augmented solar thermal plants, solar-augmented binary plants, or solar-augmented flash plants. Each one has different procedures for adding solar energy to geothermal plants (DiPippo, 2016). In the case of Peru, geothermal energy is considered to have a high potential as well as wind, solar and hydro. Figure 1 shows the different sources of electricity generation in Peru. Figures 2 and 3, respectively, show the daily solar irradiance and geothermal potential in different regions of the country.

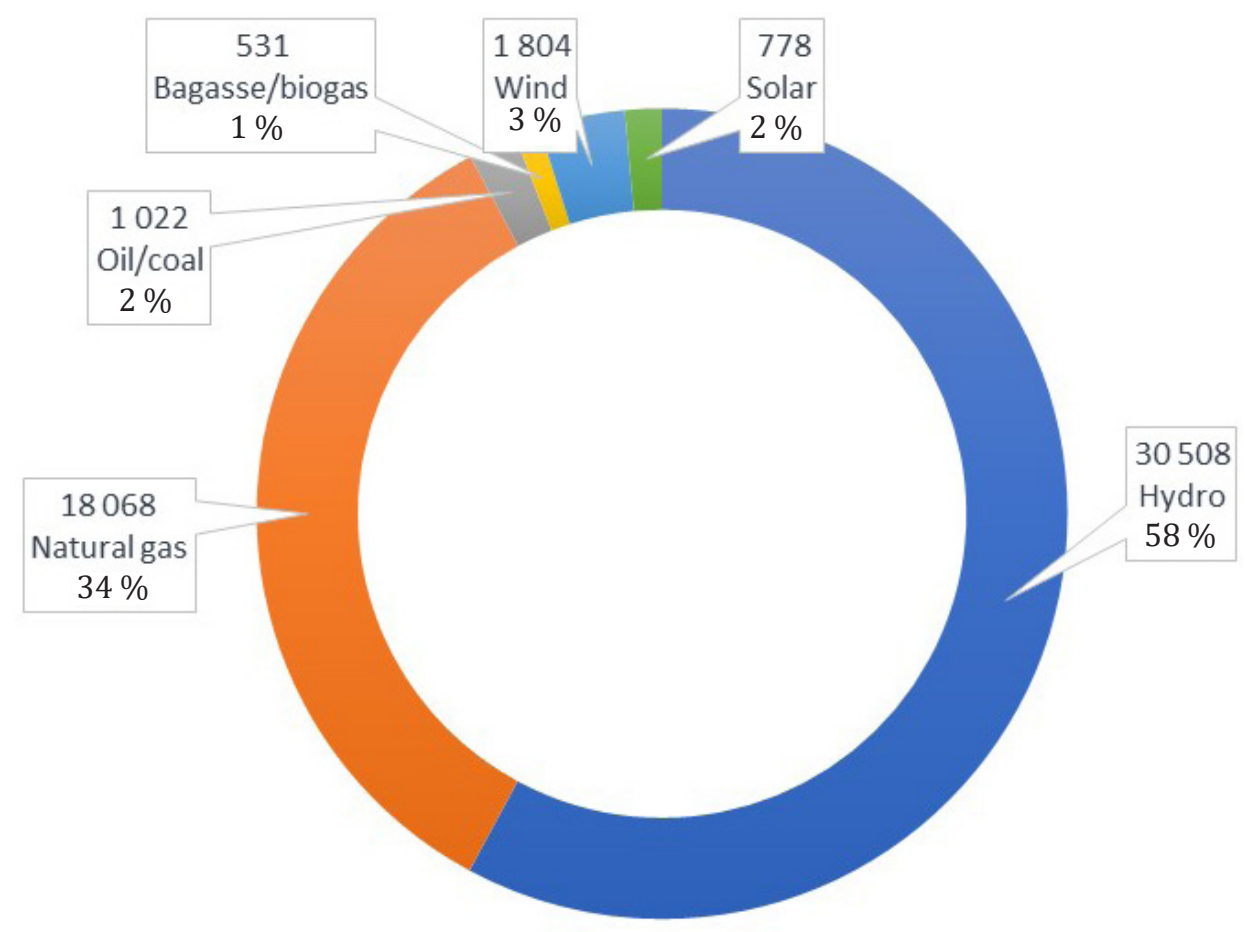

Figure 1. Energy generation by type in 2020, GWh and \% of total

Source: MINEM (2020) 


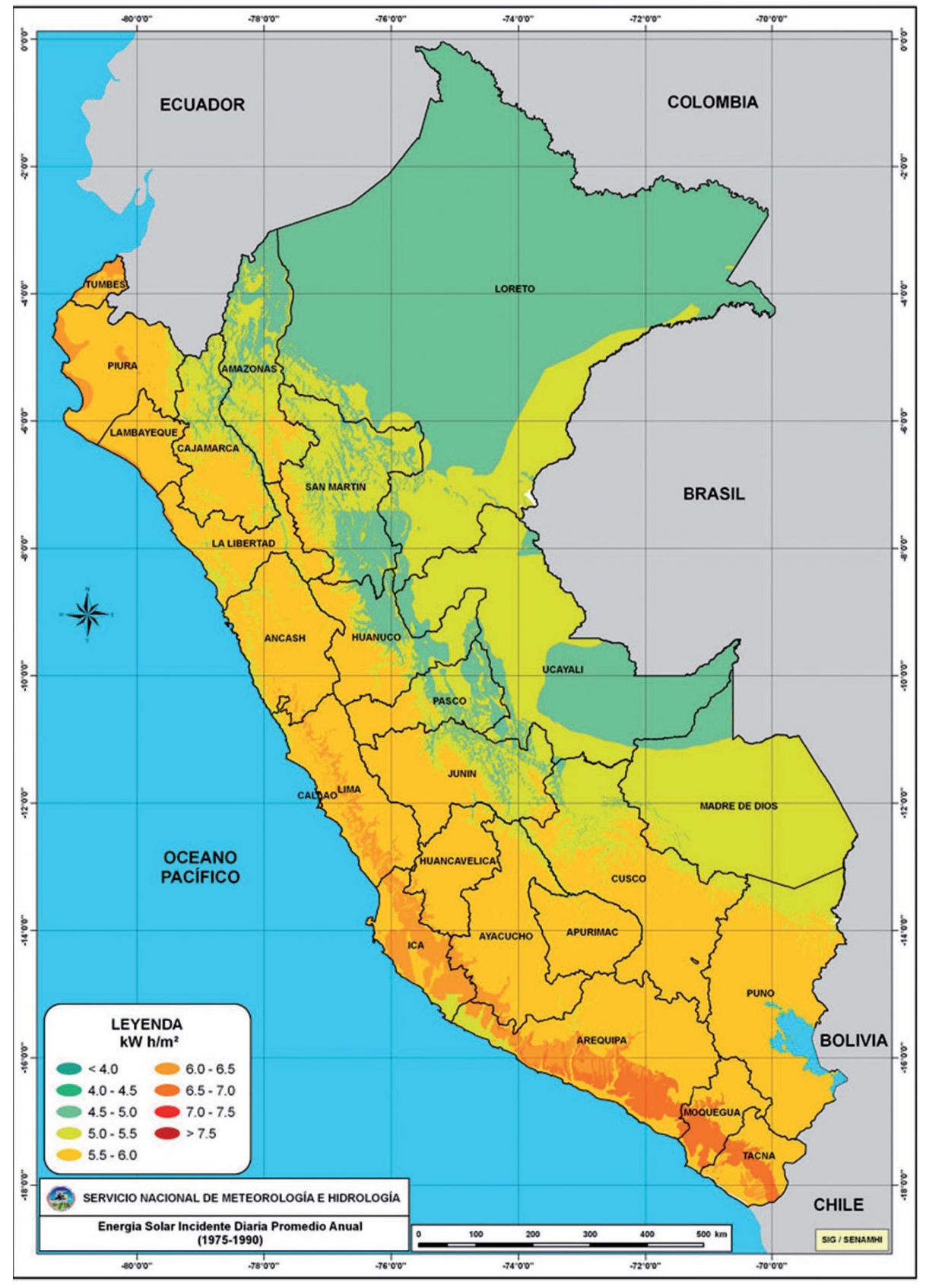

Figure 2. Daily solar irradiance in Peru (yearly average 1975-1990) Source: Osinergmin (2012) 


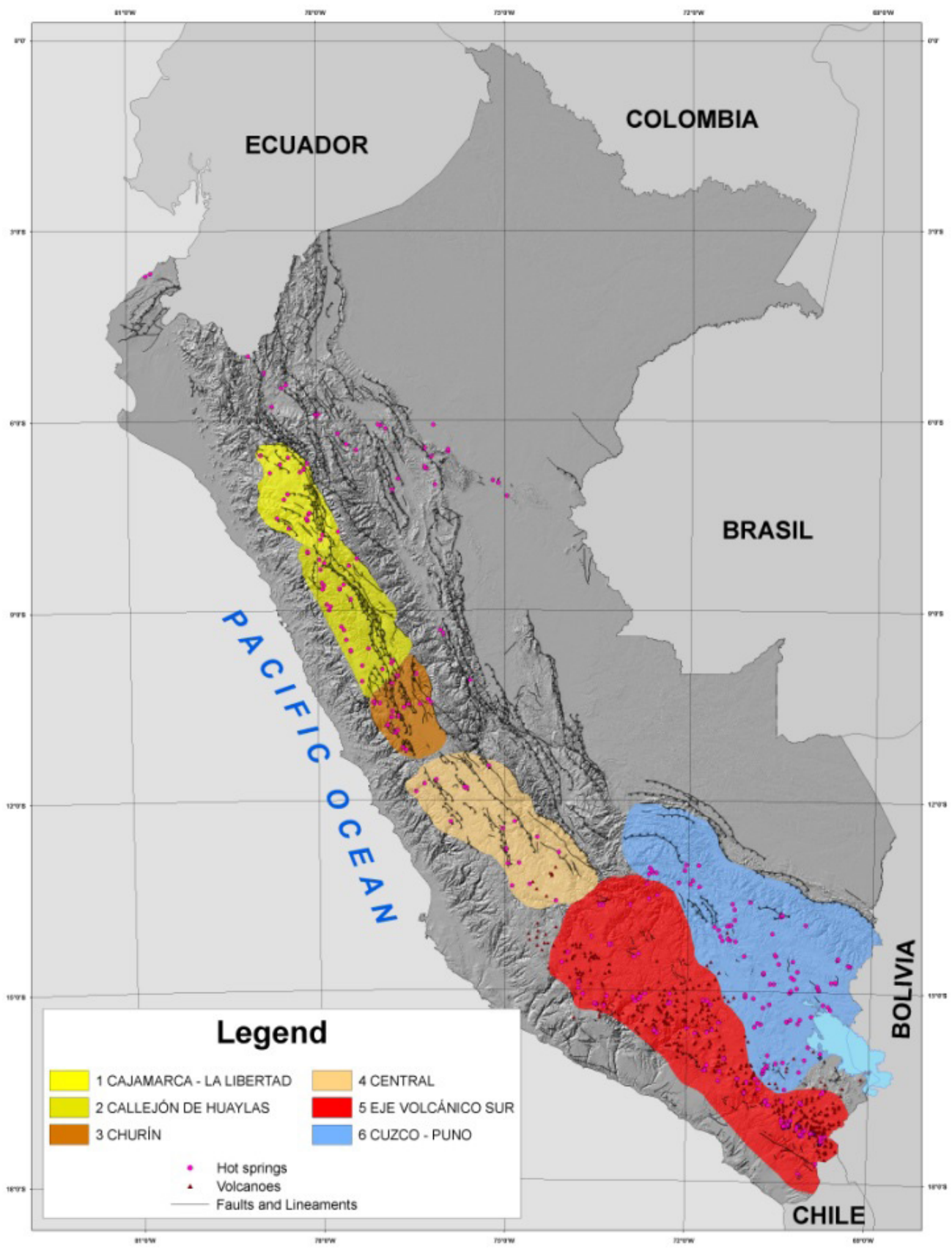

Figure 3. Geothermal energy potential in Peru

Source: West Japan Engineering Consultants (2012) 
The main objective of this research is to verify the high efficiency of a solargeothermal energy generation system, consisting of parabolic trough solar collectors, steam and refrigerant vapor turbines, and heat exchangers, using parameters of the southern region of Peru, and process simulation software CHEMCAD 7.1.5 (Chemstations, Inc). Unlike other simulations, the Geothermal Energy Conversion plant positively impacts the environment, which makes it stand out from other solutions.

This research is beneficial by providing a technological alternative that has potential in the country given that it has the necessary resources and has not been properly developed in the local market. On the other hand, installing a plant such as this one will generate multiple jobs, will provide clean energy to numerous households and will boost the development of the province in which the plant is installed.

\section{Background (reference framework)}

A scientific article on the hybrid solar-geothermal cycle for solar and geothermal energy, and a thesis from the University of Lima on a pre-feasibility study to install an electricity generation plant with parabolic trough solar concentrators in Peru, were taken as the main references.

- Solar-Geothermal Hybrid Cycle Analysis for Low Enthalpy Solar and Geothermal Resources (Greenhut et al., 2010)

This scientific article presents the study of a solar-geothermal system with base parameters and the development of two designs: the hybrid overheating and the hybrid flash. In addition, it explains the thermodynamic equations used, temperature and entropy graphs, and a simulation of the process with the Aspen Plus software (Aspen Technology Inc.).

- Pre-feasibility study for the installation of a $120 \mathrm{MW}$ electricity generation plant using parabolic trough solar concentrators (Gómez de la Torre, 2019)

This research work is similar to the scientific article that will be developed when using parabolic cylinders for electric power generation. In addition, it shows information on the regulatory framework in the country, potential demand and supply, environmental impact analysis, and economic aspects.

Likewise, various documents from the Ministry of Energy and Mines were consulted, such as the Anuario ejecutivo de electricidad 2019 (Executive Yearbook of Electricity 2019), to analyze the electricity sector by region and its indicators; the report Peru Renewables Readiness Assessment of the International Renewable Energy Agency (2014), for the evaluation of electricity production in the country by technology, the growth of energy capacity and demand, and the renewable energy auction process. In the same way, OSINERGMIN presents two 
important reports: Renewable Energies, Experience, and Perspectives in Peru's Route to Energy Transition, and The Renewable Energy Industry in Peru, 10 Years of Contributions to Climate Change Mitigation. These reports present the process of geothermal electricity generation, the costs according to the technology and its environmental impact. In addition, comparisons can be made with other types of renewable energy and which of them have a potential for development in the country.

\section{METHODOLOGY}

The process described below is of a flash hybrid plant. This type of plant (known by its full name as the solar-geothermal steam-flash/supercritical binary hybrid system) works on a more complex steam cycle concept that offers more possibilities than superheat hybrid-type plants (McKibbin et al., 2010). The flash hybrid plant is intended for low-tomoderate geothermal resources with pumped wells and starts with the solar part of the process, which uses parabolic thermal solar collectors in a closed-loop configuration.

Inside the tubes going through the collector, there is an antifreeze liquid flowing constantly. This liquid usually is Therminol VP1 (a mixture of diphenyl oxide and biphenyl). Once heated, this fluid is then sent to a heat exchanger to increase the temperature of the geothermal fluid extracted from the well (Greenhut et.al., 2010). Water deep underground, heated by the earth's natural heat, is brought to the surface and delivered to the power plant through pipes. Solar energy raises the temperature of the pressurized geofluid (hot well water) to a sufficiently high value (roughly saturation) to allow flashing at an appropriate pressure.

This generates steam and hot brine for use in a steam turbine and preheating the working fluid in the binary loop. The separator allows the steam to drive one of the two turbines connected to a common generator. Pressure from the vapor spins the turbines, which in turn spin the electric generator. For a flow rate of $100 \mathrm{~kg} / \mathrm{s}$ of geothermal fluid, each unit can generate about $280 \mathrm{~kW}$, and by combining more units and scaling up the flowrate, about $11 \mathrm{MW}$ net power can be generated in this first phase of the plant.

After leaving the turbine, the vapor moves downward into the low-temperature heat exchangers. Here, the R-134a fluid enters the heat exchanger and circulates through it, changing to vapor and cooling and condensing the steam, allowing it to condense back into a fluid collected at the bottom of the tank and pumped back to the injection well. The working fluid (R134a) vapor is expanded in the binary turbine (BT), generating more power, and is converted back to liquid by exchanging heat with atmospheric air. 


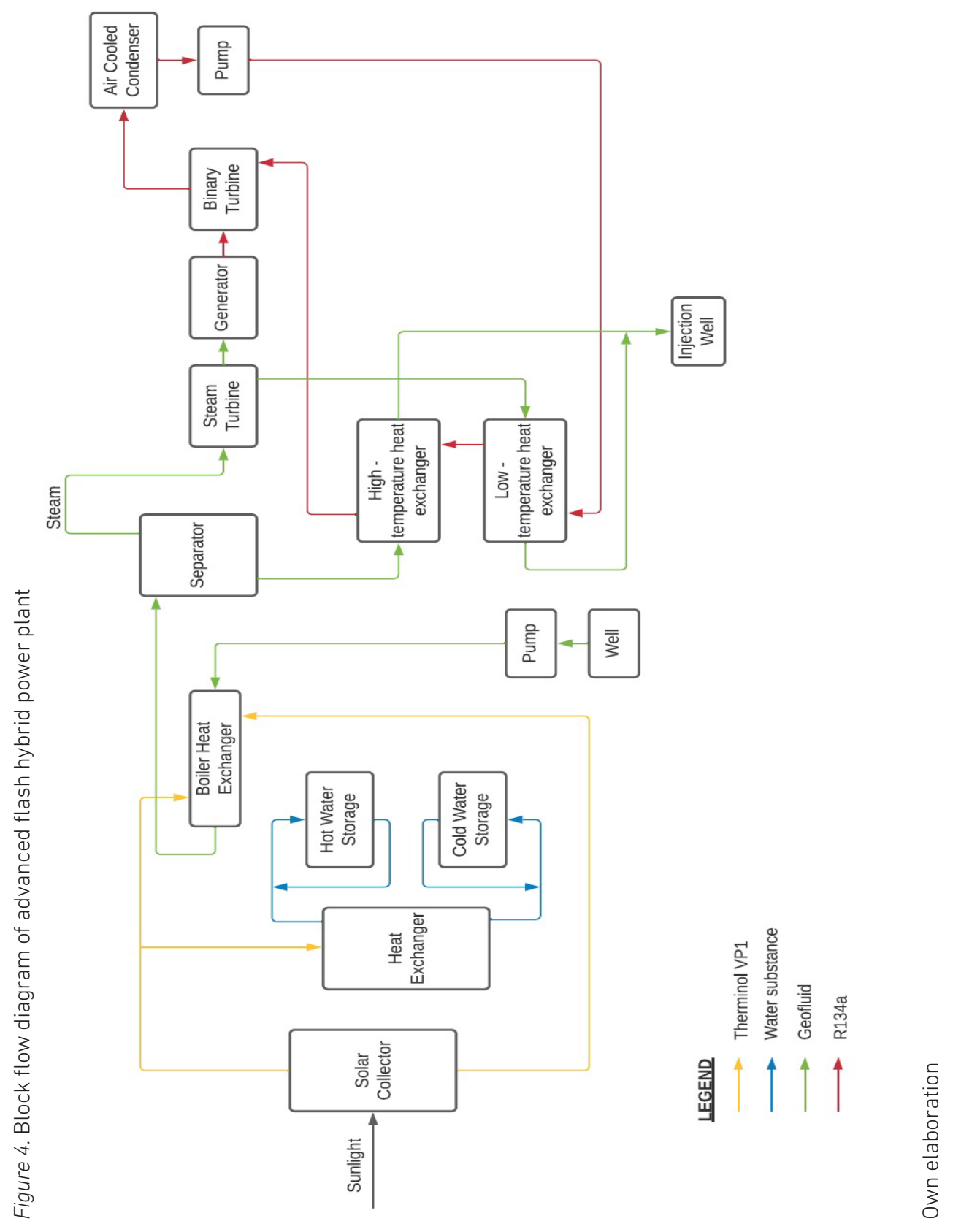


In order to carry out the simulation, it is necessary to define which area of Peru would be a potential site for the development of a geothermal plant. For this purpose, quantitative research was carried out in the north, south, east, and west of the country using GDP, installed power, and total energy consumption as indicators. These were chosen because they allow us to determine the economic growth, evaluate the amount of installed energy and the total energy consumption for the possible demand of the area, respectively.

According to Franklin Acevedo, CEO of Energy Development Corporation Peru, the country's southern region presents a high potential for the development of geothermal energy due to its location over the so-called Ring of Fire, which presents multiple volcanic manifestations and constant seismic activity. In 2017, the south region had a GDP of 110962 million PEN, an installed power of 3,924 MW with an average annual growth of $11,9 \%$, and a total consumption of $15140 \mathrm{GWh}$; these indicators show greater annual growth compared to the north, center and east regions (Ministerio de Energía y Minas, 2019). Both indicators, the location close to the Ring of Fire and the growth of the indicators mentioned above compared to other geographic areas, make the southern region an ideal area for installing a geothermal plant.

The software used for the simulation, CHEMCAD 7.1.5 (Chemstations, Inc.) is an integrated suite of intuitive chemical process simulation software that fits into the chemical engineering workflow and supercharges the efficiency of any chemical process applicable. All modules work within a single graphical user interface and is highly customizable, flexible, and affordable. With its help, mass flow, temperature, and pressure parameters were easily calculated throughout the entire process, considering all physical, thermodynamical, and chemical constraints.

This software contains libraries of chemical components, thermodynamic types, and facilities to manage steady-state simulation using larger and larger scale interconnected processes, allowing to adjust its characteristics to those required by the user to simulate the desired chemical process and obtain the results of how it would work in reality.

Based on the article mentioned before, Solar-Geothermal Hybrid Cycle Analysis for Low Enthalpy Solar and Geothermal (Greenhut et al., 2010), we were able to determine the necessary equipment according to their efficiency and rating as follows:

- Pumps

- Solar collectors

- Heat exchanger

- Flash tank

- Steam/binary turbine

- Generator

- Condensator 
The following substances were used for the simulation:

- Therminol VP1, as heat transfer fluid

- Water, as geothermal fluid

- R134a refrigerant, as the binary fluid

- Air, as cooling fluid

Although setting up and running a CHEMCAD simulation requires some training and knowledge of basic thermodynamics, the process may be summarized in the following steps:

- Choose the appropriate engineering units (SI in our case).

- Create the flowsheet with the appropriate streams and unit operations (i.e., process steps).

- Select the substances (chemical components) involved with corresponding ranges of pressure and temperature. According to these parameters, the thermodynamics wizard will choose the appropriate thermodynamic model.

- Define the feed streams used in the process.

- Enter specifications for the unit operations.

- Run the simulation and review the results.

Since this process is quite complex, involving several streams of different fluids, the simulation cannot be performed at once, so it must be constructed and tested gradually. In this case, we started with the geothermal fluid, then added the heat transfer fluid for superheating the geofluid, the flashing stage, the steam turbine, the binary fluid, and so on. Needless to say, that some simulations will not easily converge in the first attempt. So, the flow rates must be adjusted, performing some precalculations separately. Once the simulation for the whole process converges, slight adjustments in flow rates, temperature, and pressure are made to optimize the results.

For this research, the base information for the process simulation derives from a study performed in Bali, Indonesia, titled Solar-Geothermal Hybrid Cycle Analysis for Low Enthalpy Solar and Geothermal Resources presented in the Proceedings World Geothermal Congress in 2010 (Greenhut et al., 2010). This study illustrates the difference between two types of solar geothermal energy conversion systems, with the goal being to find hybrid solutions that could take some advantage of the potential synergies of the solar thermal and geothermal power cycles. In conclusion, the Greenhut study demonstrated the efficiency level of both types of plants, giving as a result that the one with better percentage was the hybrid flash design exemplified in the paper mentioned above. The data used from this source for the simulation will be listed below:

- Geothermal fluid mass flow: $100 \mathrm{~kg} / \mathrm{s}$ 
- Geothermal fluid temperature: $150^{\circ} \mathrm{C}$

- Turbine efficiency: $85 \%$

- Pump efficiency: $80 \%$

The model for the process that allowed us to make the simulation was built starting with supercritical steam and R-134a refrigerant as the binary fluid. A flash tank, steam cycle, and solar cycle were added as well. Regarding the parameters used, the design was based on a supercritical binary cycle of R134a, due to its cooling performance and lower input energy required than other binary fluids and supercritical cycles (Meyer, 2001). The cycle was restricted to the following parameters:

- Geothermal fluid mass flow: $473 \mathrm{~kg} / \mathrm{s}$

- Geothermal fluid initial temperature: $37,2^{\circ} \mathrm{C}$

- Geothermal fluid final temperature: $71,2^{\circ} \mathrm{C}$

- Final condenser output temperature: $20^{\circ} \mathrm{C}$

- Final condenser output pressure: $1 \mathrm{~atm}$

- Air result mass flow: $2942 \mathrm{~kg} / \mathrm{s}$

\section{RESULTS}

The first results were obtained in a flash tank, which separates the steam from the hot brine. The steam comes out from the top of the flash tank with a flowrate of $22,5 \mathrm{~kg} / \mathrm{s}$, a temperature of $200^{\circ} \mathrm{C}$, and a pressure of 15,5 bar. On the other hand, the stream of hot brine comes out from the bottom of the flash tank with a mass flow of $77,5 \mathrm{~kg} / \mathrm{s}$ at the same temperature and pressure as the steam $\left(200^{\circ} \mathrm{C}, 15.5\right.$ bar). As both fluids continue the process, the steam enters the steam turbine, coming out at $125,4^{\circ} \mathrm{C}$, and 2,35 bar, generating $4,89 \mathrm{MW}$ of power. Meanwhile, the brine goes into the first condenser and acts as the heating fluid against the working fluid (R-134a). This allows the latter to increase its temperature from $37,2^{\circ} \mathrm{C}$ to $71,2^{\circ} \mathrm{C}$, keeping a mass flowrate of $473 \mathrm{~kg} / \mathrm{s}$. The second condenser works with the steam coming from the steam turbine as the heating fluid against the working fluid, allowing it to increase its temperature once again, this time from $71,2{ }^{\circ} \mathrm{C}$ to $113^{\circ} \mathrm{C}$ and keeping its mass flow and pressure at $473 \mathrm{~kg} / \mathrm{s}$ and 50 bar, respectively.

The last part of the process consists of the binary turbine, which works with the R-134a fluid, cools it down to $51,1^{\circ} \mathrm{C}$ and reduces the pressure to 13,5 bar, generating $7,08 \mathrm{MW}$ of power (about $45 \%$ higher than the steam turbine). In that state, it enters the last condenser (like in an air conditioning machine), and exchanges heat with the ambient air, which enters the condenser at flow rate of $2942 \mathrm{~kg} / \mathrm{s}, 20^{\circ} \mathrm{C}$ and $1.01 \mathrm{bar}(1 \mathrm{~atm})$. The hot air exits at $44,6^{\circ} \mathrm{C}$, an ambient pressure. The results are presented in the process flow diagram (figure 5). 


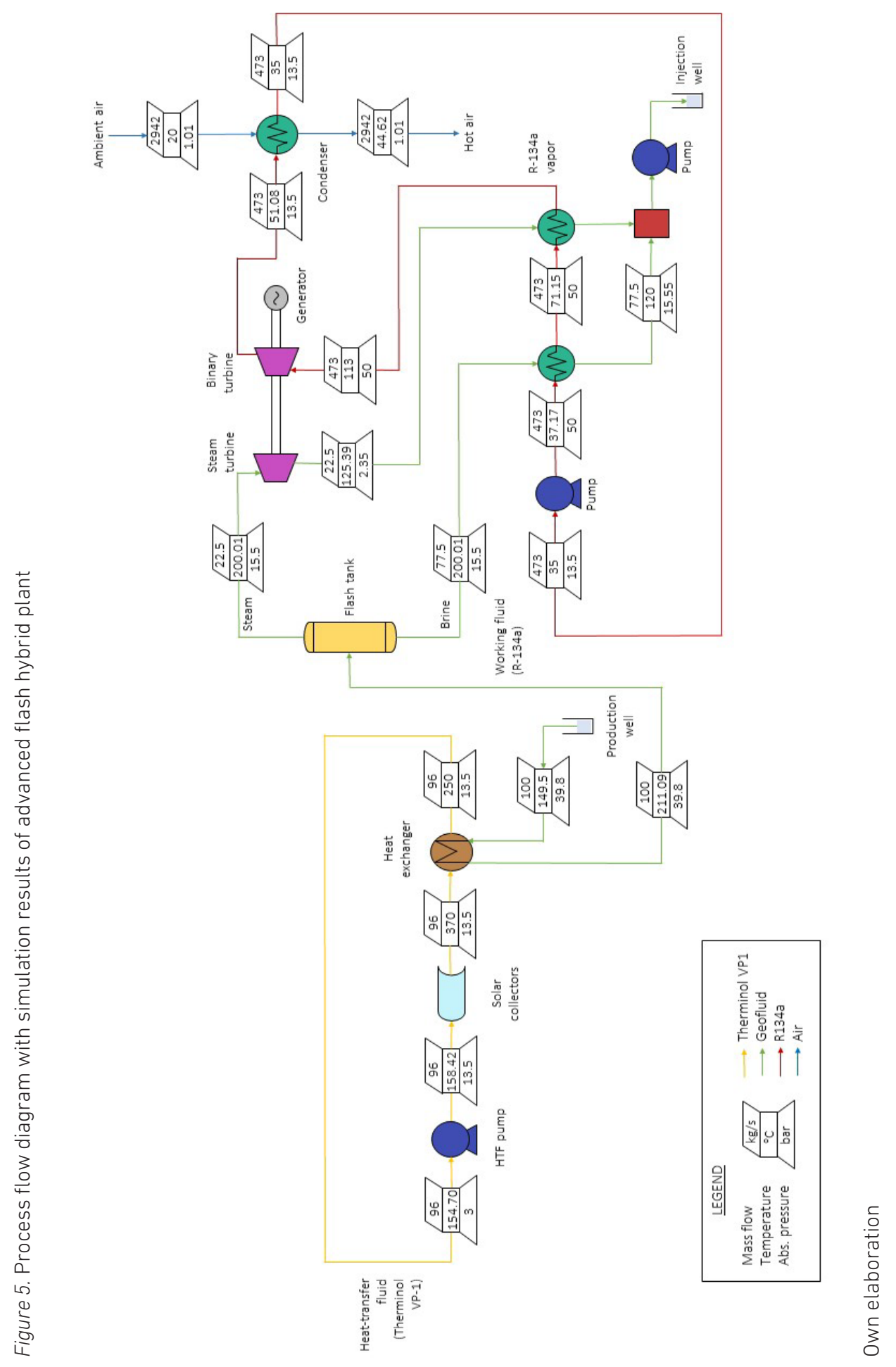




\section{DISCUSSION}

- The simulation results indicate that this type of advanced flash hybrid plant is feasible, reaching a combined energy production of about $120 \mathrm{~kJ} / \mathrm{kg}$ geofluid. This value may seem low compared to a coal or gas-fired power plant, but considering that no fossil fuels are burned and no emissions generated, the potential of geothermal energy is very promising.

- In order to take this research to a prefeasibility study or an investment project level, more technical details must be considered, for instance, all the losses in equipment, pipes, and connections, which were considered as ideal in this simulation. Also, a detailed exergy (maximum useful work) analysis must be performed, in order to know the real limits of this plant.

- In Peru, there is a great geothermal potential in the southern region of the country due to multiple volcanic manifestations and, on the other hand, due to having a higher GDP, installed power, and higher per capita consumption than in the northern, center and eastern regions.

- For the simulation, we used CHEMCAD 7.1.5 software. This allowed us to see how all these chemical processes would work properly with the right conditions through all the simulations mentioned in chapter 3 , producing satisfactory results. These conditions are aligned and are proportional to our base article: Solar-Geothermal Hybrid Cycle Analysis for Low Enthalpy Solar and Geothermal (Greenhut et al., 2010). Although a more thorough analysis is required for this type of project, the authors consider that this scientific paper is a good starting point, and it will encourage further research in this area, and hopefully, and possibly the realization of more investment projects in sustainable energy.

- According to the Ministry of Energy and Mines, Peru ranks first in South America for its level of exploration due to the availability of geothermal resources. The country could generate up to $2860 \mathrm{MW}$ in 61 geothermal fields based on the distribution of hot springs and other hydrothermal manifestations located mainly in Arequipa, Moquegua, Tacna, and Puno. (Ministerio de Energía y Minas, 2011).

- This type of plant generates renewable energy that does not depend on weather conditions; safe energy, since it does not require combustion, gases or fuel deposits; energy whose heat source is natural, inexhaustible and therefore does not experience price increases; clean energy, with low carbon emissions. In short, a complete and highly beneficial plant for everyone, compared to other types of power plants (Energy Development Corporation, 2020).

- For geothermal energy, we can say that the best hybrid configuration, low energy, and low-cost heat source, should be used to the maximum extent possible within 
its temperature limits. Unlike solar energy, it should be used only to extend the temperature above the temperature of the low-cost heat source.

\section{REFERENCES}

Akella, A., Saini, R., \& Sharma, M. (2009). Social, Economical and Environmental Impacts of Renewable Energy Systems. Renewable Energy, 34(2), 390-396. doi:10.1016/j. renene.2008.05.002

Burguillo, M., \& Del Río, P. (June 2008). Assessing the Impact of Renewable Energy Deployment on Local Sustainability: Towards a Theoretical Framework. Renewable and Sustainable Energy Reviews, 12(5), 1325-1344. doi:10.1016/j. rser.2007.03.004

Comité de Operaciones del Sistema Interconectado Nacional. (2020). Indicadores BI Producción acumulada. http://www.coes.org. pe/portal/

Currie, S. (May 2016). Renewable Energy in Latin America: Peru. Mondaq. https://www. mondaq.com/peru/renewables/495452/renewable-energy-in-latin-america-peru

Dincer, I. (June 2000). Renewable Energy and Sustainable Development: A Crucial Review. Renewable and Sustainable Energy Reviews, 4(2), 157-175. doi:10.1016/ S1364-0321(99)00011-8

DiPippo, R. (2016). Geothermal Power Plants. Principles, Applications, Case Studies and Environmental Impact. $4^{\text {th }}$ ed. Butterwoth-Heinemann.

Energy Development Corporation. (2020). EDC en Perú. https://edc.com.pe/edc-en-peru

Gómez de la Torre, A. (2019). Pre-Feasibility Study for the Installation of a 120 MW Electricity Generation plant Using Parabolic Trough Solar Concentrators. [Tesis de titulación, Universidad de Lima]. https://repositorio.ulima.edu.pe/ handle/20.500.12724/11240

Greenhut, A., Tester J., DiPippo R., Field R., Love C., Nichols K., Augustine C., Batini F., Price B., Gigliucci G., \& Fastelli I. (2010). Solar-Geothermal Hybrid Cycle Analysis for Low Enthalpy Solar and Geothermal Resources. Proceedings World Geothermal Congress 2010. Bali, Indonesia. https://www.geothermalenergy.org/ pdf/IGAstandard/WGC/2010/2615.pdf

InfOsinergmin. (2012) Edición especial sobre generación con RER. Osinergmin. http:// www2.osinerg.gob.pe/Publicaciones/pdf/InfoOsinerg/Infosinergmin_edicionespecialp2_empresas_2012.pdf 
Lentz, Á., \& Almanza, R. (2006). Solar-Geothermal Hybrid System. Applied Thermal Engineering, 26(14-15), 1537-1544.

Lund, J. W. (April 2018). Geothermal energy. Encyclopedia Britannica. https://www.britannica.com/science/geothermal-energy. Accessed September 11th 2021.

Mendoza, E., y Pérez, V. (January 2010). Renewable Energy Sources and Social Movements in Latin America. Instituto de Estudios Internacionales - Universidad de Chile. https://www.jstor.org/stable/41392132?seq=1

Meyer, J. P. (2001). The Performance of the Refrigerants R-134a, R-290, R-404A, R-407c and R410A in Air Conditioners and Refrigerators. Journal of Mechanical Engineering,47(8), 366-373. https://www.sv-jme.eu/?ns_articles_pdf=/ns_articles/files/ojs3/1373/submission/1373-1-2423-1-2-20171107.pdf\&id=4754

Ministerio de Energía y Minas. (January 2020). Principales indicadores del sector eléctrico a nivel nacional. MINEM. http://www.minem.gob.pe/minem/archivos/1\%20 Cifras\%20preliminares\%20del\%20Sector\%20Electrico\%20-\%20Diciembre\%20 2020\%20-\%20Ver\%200(1).pdf

Ministerio de Energía y Minas. (2019). Anuario Ejecutivo de Electricidad. MINEM. minem. gob.pe/minem/archivos/AnuarioEjecutivoFinal-Rev-Final2.pdf

Ministerio de Energía y Minas. (February 2012). Plan Maestro para el desarrollo de la energía geotérmica en el Perú. MINEM. https://openjicareport.jica.go.jp/pdf/12048567.pdf

Ministerio de Energía y Minas. (2011). El Perú tiene una gran disponibilidad de recursos geotérmicos. MINEM. http://www.minem.gob.pe/descripcion.php?idSector=6\&idTitular $=3860$

McKibbin, R., Fowkes, N., Florio, B., \& Horowitz, F. (January 2010). Geothermal Data Analysis and Optimization. Proceedings of the 2010 Mathematics and Statistics in Industry Study Group, MISG-2010. 52. 10.21914/anziamj.v52i0.3600.

National Geographic. (n. d.). Geothermal Energy. National Geographic. https://www.nationalgeographic.com/environment/article/geothermal-energy

Osinergmin. (December 2012). Energías renovables en el plan estratégico de energías sostenibles y bioenergía. Infosinergmin, Edición Especial, 14(10) EE 02-2012. http://www2.osinerg.gob.pe/Publicaciones/pdf/InfoOsinerg/Infosinergmin _ edicionespecialp2_empresas_2012.pdf

Osinergmin.(2013).Introducciónalasenergíasrenovables.Osinergmin.http://www2.osinerg. gob.pe/EnergiasRenovables/contenido/IntroduccionEnergiasRenovables.html

Osinergmin. (2020). Energía geotérmica. Osinergmin. https://www.osinergmin.gob.pe/ empresas/energias-renovables/energia-geotermica 
Potencial geotérmico peruano equivale al $50 \%$ de la electricidad que producimos. (February 2020). Rumbo Minero. http://www.rumbominero.com/noticias/ energia/potencial-geotermico-peruano-equivale-al-50-de-la-electricidad-queproducimos/

The International Energy Agency [IEA]. (2018). Renewable and non-renewable electricity generation in OECD countries, 2008-2018. https://www.iea.org/ data-and-statistics/charts/renewable-and-non-renewable-electricity-generation-in-oecd-countries-2008-2018

Schmerler, D., Velarde, J., Rodríguez, A., \& Solís, B. (Eds.). (2019). Energías renovables: experiencia y perspectivas en la ruta del Perú hacia la transición energética. Osinergmin.

Sistema de Información de Energías Renovables. (2020). Osinergmin. https://www.osinergmin.gob.pe/empresas/energias-renovables/subastas

U.S. Energy Information Administration. (2010). Updated Capital Cost Estimates for Electricity Generation Plant, pp. 128-141. http://large.stanford.edu/courses/2016/ ph241/long1/docs/updatedplantcosts.pdf

Vásquez, A., Tamayo, J., \& Julio S. (2017). La industria de la energía renovable en el Perú: 10 años de contribuciones a la mitigación del cambio climático. Osinergmin. https:// www.osinergmin.gob.pe/seccion/centro_documental/Institucional/Estudios_ Economicos/Libros/Osinergmin-Energia-Renovable-Peru-10anios.pdf

West Japan Engineering Consultants. (2012). Plan Maestro para el Desarrollo de la Energía Geotérmica en el Perú. MINEM. https://openjicareport.jica.go.jp/pdf/12048567.pdf 